University of New Hampshire

University of New Hampshire Scholars' Repository

8-2016

\title{
Outliving Love: Marital Estrangement in an African Insurance Market
}

Casey Golomski

University of New Hampshire, Durham, casey.golomski@unh.edu

Follow this and additional works at: https://scholars.unh.edu/anth_facpub

Part of the African Languages and Societies Commons, African Studies Commons, Civil Law Commons, Domestic and Intimate Partner Violence Commons, Family Law Commons, Family, Life Course, and Society Commons, Insurance Law Commons, Law and Gender Commons, Law and Society Commons, Social and Cultural Anthropology Commons, Social Control, Law, Crime, and Deviance Commons, Sociology of Culture Commons, and the Women's Studies Commons

\section{Comments}

This is an Author's Original Manuscript of an article published by Taylor \& Francis in X in Y, available online: https://dx.doi.org/10.1080/02533952.2016.1197510

\section{Recommended Citation}

Golomski, Casey, "Outliving Love: Marital Estrangement in an African Insurance Market" (2016). Social Dynamics. 9.

https://scholars.unh.edu/anth_facpub/9

This Article is brought to you for free and open access by the Anthropology at University of New Hampshire Scholars' Repository. It has been accepted for inclusion in Anthropology Scholarship by an authorized administrator of University of New Hampshire Scholars' Repository. For more information, please contact Scholarly.Communication@unh.edu. 


\title{
Outliving love: marital estrangement in an African insurance market
}

\section{Casey Golomski ${ }^{\text {a.b }}$}

a Department of Anthropology, University of New Hampshire, Durham, NH

b Department of Anthropology, University of the Witwatersrand, Johannesburg, South Africa

\begin{abstract}
Marital estrangement and formal divorce are vital conjunctures for married women's kinship relations and life course, when a horizon of future possibilities are revalued and negotiated at the interstices of custom, law, and social and ritual obligations. In this article, after delineating the forms of customary and civil marriage and the possibilities for divorce or estrangement from each, I describe how some married women in Swaziland and South Africa mediate this complex social field for their children and families through pensions and continuing to pay for their partners' insurance coverage. This was not solely out of avarice to reap future benefits as spouses. Rather, in a context of patriarchal relations, gender-based violence and economic dispossession, women seek to maintain potential financial grounds through insurance resources, acknowledge their children's paternity, and fulfill enduring obligations to in-laws by partially contributing to the eventual funerals of their spouses and kin.
\end{abstract}

KEYWORDS: Divorce, gender inequality, kinship, life insurance, secrecy, Swaziland

\section{Running title: Outliving love Notes on contributor}

Casey Golomski is an Assistant Professor of Anthropology at the University of New Hampshire and a Visiting Researcher at the University of the Witwatersrand. . His research on medicine, 
cultural economies, and religion and has appeared in Material Religion, African Journal of AIDS Research, and American Ethnologist.

Address correspondence to:. Email: c.golomski@gmail.com 


\section{Introduction}

Tsandzile is in her thirties and works in financial services in downtown Mbabane, the largest city in Swaziland. A few years ago she was married in customary rites, publically smeared with red ochre, kugcotjwa libovu, for the initial betrothal ceremony of kuteka. With her husband, she had had a son prior to this public betrothal, and they lived together outside of the city. Two years after the wedding, Tsandzile attended her workplace's annual party, and she and her colleagues spent Friday and Saturday enjoying music, barbecuing, and gossiping. On Sunday, she returned home with a family-sized serving of chicken and side dishes from KFC for dinner. The husband told her KFC was not good enough, and that he expected home-cooked chicken. Tsandzile told him she was tired from her weekend recreation and in any case, she thought that KFC would be special. Tsandzile's husband proceeded to beat her viciously. She was knocked unconscious, and when she woke up on Monday, she packed her things and left with her son. Her 'divorce' was now imminent - although in Swaziland, it is often said there is no such thing as divorce from a customary marriage - hence the scare quotes.

Over cool drinks in the smoking room of a popular chain restaurant, I asked Tsandzile how this process would unfold. She and her son had moved out of the house completely, first living with her parents and then finding their own flat in Mbabane. She had left with her bedding, clothes, dishes, and personal items, and so she was well sorted in her new home. Given her position in the financial services sector, I also asked about money. The two had separate bank accounts, but they were both subscribed to a term life insurance policy taken out by Tsandzile to cover their respective burials. I asked her if she would cancel the policy. She shifted in her seat and smiled, saying, "no.”

Why would Tsandzile, like several other women I met in Swaziland who were facing social crises of marital estrangement, continue to pay insurance coverage for their spouses? What 
forms of economic, social, and cultural value and aspirations are at play in their actions? How can these crises be read into anthropological approaches to kinship, life course and social reproduction, and how might attention to something like insurance be an innovative vector of insight? In this article, I explore these questions by describing several conflicting iterations of marital obligations within a wider field of competing legal systems and familial social relations, and I consider what happens when marriages break down. By maintaining insurance coverage for estranged or divorced spouses, women can make claims on eventual deaths. They can use part of the cash to support themselves and their children, and part of their policies to pay for their (ex-) husbands' funerals, thereby fulfilling continuing obligations of ritual exchange or care for children who still nominally belong to their husbands' patrilines.

Employing demographic methods, anthropologist Jennifer Johnson-Hanks (2002) argues that descriptions of the movement through the life course should move away from models of rites of passage and coherent ideations of life stages, and toward a notion which she coins "vital conjunctures." While she conceptualises life stages as forms of social life produced through institutions, such as marriage, she notes that institutions' abilities to function successfully in this way vary widely. Vital conjunctures are a way to conceptualise the slippage or intersection between aspirations and institutions. Using evidence from young Beti women in Cameroon, Johnson-Hanks shows how marriage, motherhood, and education as passages are only variably achieved andmost often through long-term negotiations and social and economic disruptions. Marriage, for example, may never be realized as a social status, or only partially, insofar that, “potential futures are under debate and up for grabs" (Johnson-Hanks 2002, 872) in women's lives

While Johnson-Hanks focuses on marriage and childbearing in particular, she notes that "all major life events - including migration, illness, and career change - can be construed as" vital conjunctures (Johnson-Hanks 2002, 871). In this respect, I think through marital estrangement and 
divorce as potent conjunctures for women and the complex family systems and emotions in which they are imbricated. Women in Swaziland often invoke the English term 'divorce' to describe what can be objectively identified as a dynamic of marital estrangement, meaning that spouses may no longer cohabit or provide emotional, social or material support for each other, yet are not legally or formally divorced per locally relevant legal systems. As elsewhere in postcolonial Africa and worldwide, marriage, divorce, and kinship are messy as both conceptual objects and personal experiences, and they have been historically transformed and gendered in law, ritual events, work, and social actions through the life course. A person's transition from married to not is rarely so final, and relations between wives, husbands, children, extended families, and others may become estranged but remain entangled in affections and actionable obligations like care for children and participation in ritual events like funerals. As I will show, forms of marriage in Swaziland are social, public, and often gender unequal. Divorces are rarely formalised or institutionalised, leading to a consideration of ways women may seek out alternative social and economic futures. Insurance consumption, an interestingly secretive process, has become one way to work toward these futures while still maintaining marital obligations that 'outlive love' between spouses. ${ }^{1}$

These topical and theoretical intersections are novel in anthropology and related fields in Africa. Studies linking divorce and insurance tend to focus on the United States and on the loss of health insurance versus life insurance for women, children and others who are economically vulnerable (Lavelle and Smock 2012, Peters, Simon and Taber 2014, Ellis 2003), while Africanist anthropologists are freshly considering the effects of popular financial consumables like insurance on kinship and the life course (Golomski 2015, James 2015, Livingston 2009). Indeed, in their feminist approach to capitalism, Bear, Ho, Tsing, and Yanagisako (2015) contend that the economy can only be understood with historical regards to forms of gendered, familial sociality. Despite the legion historical literature on transformations to gender, sexuality, and kinship under 
colonialism, there is little ethnographic work on divorce in Africa amid contemporary, changing economies (Stiles 2003, 2005, Dorjahn 1990, Medeiros 2014). Hamilton Sipho Simelane (2011) has moved in this direction in post-colonial Swaziland, describing how some women estrange themselves from abusive marriages by engaging in economic activities like wage labour. Finally, recent approaches to the anthropology of the life course have not considered forms of divorce as significant social and personal transformations or transitions (Lynch and Danely 2013).Marital estrangement and divorce are a life crises and portend momentous re-configurations of kinship and prospects for others' and one's own wellbeing in later life, including a dignified burial in this case here. These crises and re-configured relations are mediated through economic and medical forms like grants for children, elderly and disabled persons, pensions, wills, and insurance.

Methodologically, I draw on document and ethnographic research and interviews conducted between 2009-2015 with families, lawyers, social services professionals and those working in the life insurance industry in Swaziland and nearby ethnically Swazi communities in the Mpumalanga Provinces in South Africa. ${ }^{2}$ My initial research on insurance formed part of a project focused on death, dying and funerals as sites of cultural change, where new term life policies turned out to be resourceful yet morally circumspect consumables through which people remade kinship (Golomski 2015). I revisited the majority of the data collected in observations of policy presentations, interviews with insurance industry personnel, and ethnographic encounters with ordinary women between 2010 and 2011, expanding it to include interviews in 2014 and 2015 with lawyers and follow-ups with the same and other women. This was prompted by a rereading of the original data coupled with the researcher's greater attunement toward local dynamics of gender inequality. Re-analysing and expanding one's data in this way can align with feminist-minded approaches by challenging the researcher's previous, biased interpretive 
assumptions which can in turn repress already disadvantaged women as interlocutors by reproducing gendered ideologies about them (Lloyd, Emery, Klatt 2009: 270).

In order to best situate Tsandzile and other women's social and economic actions, I first delineate the changing fields of marriage and estrangement and divorce. I then describe how married persons and their kin forge social relations in a new life insurance market. I follow this with a few cases of estranged women to show how personal aspirations and anticipated social obligations are imagined through continued insurance consumption. In conclusion, I reconsider the ways that technologies like life insurance become the grounds to engender kinship, life course, personal wellbeing and forms of familial care amid vital, often violent conjunctures, and what love has to do with it..

\section{Marriage and divorce, civic and customary: ritual, obligation, and inequality}

First, it is necessary to take an ethnographic tour through the particular forms of marriage, divorce, and law in Swaziland, a small socially and politically traditionalist country in southeastern Africa with a population of about 1.3 million. Doing so contextualises how cultural values and actions of kinship are negotiated amid contemporary social and economic forces. The contractual obligations of marital life there operate via two distinct, yet ever-changing and overlapping legal systems, one being Swazi Law and Custom (SLC) and the other being Roman-Dutch civil law, both of which were institutionalised under British colonialism (Nhlapo 1992). The dual system poses many practical challenges for ordinary citizens, and the systems' intersections are constantly debated in daily conversations and legislative and judicial forums.

\section{Forms of marriage}


Marriages fall into two categories: customary and civic. Thandabantu Nhlapo (1992) describes the two forms of marital law as derived from several customary and foreign forms, congealing in colonial-era legislation such as the Swazi Courts Act 80 of 1950 and the Marriage Act 47 of 1964. These laws specify marriage as between a man and a woman. While there are no laws officially banning same-sex marriage, there is widespread discrimination against the LGBT population (US Department of State 2011, Risher et al. 2013, Kennedy et al. 2013). Far more marriages are undertaken via SLC. According to 2014 statistics from the Ministry of Home Affairs, 16,010 couples reported marrying under SLC versus 9,895 by civil rites (Khumalo 2015). ${ }^{3}$ The majority of Swazi citizens live a greater proportion of their social lives by customary tenets. In the countryside especially, where most Swazi reside, marriages, births, deaths, family disputes, kukhonta loyalty and residence pledges, development projects, and global health and humanitarian initiatives are all registered with or mediated by chiefly councils of older men, emabandlancane, who then report these to the Ministry of Home Affairs.

Customary marriages are largely heteronormative. They may be arranged or based on loveand come into being through a series of rites involving social commitments by both the man's and the woman's families, which progressively incorporate a woman into the man's patriline and, importantly, locate children born from the marriage there as well (Kuper 1947). The obligation to bear children constitutes women's identities as part of a marital relationship, with infertility and other complications biasing toward them(Nyawo 2015). Indeed, if children are born out of wedlock, families negotiate fines of inhlawulo to mitigate shame and acknowledge the child's paternity; women as mothers remain the primary caregivers (Mkhwanazi 2014)... Kuteka, a betrothal rite, initiates marriage following families' negotiations and consent. The woman ceremoniously enters the man's family's cattle pen to weep publically, and an old woman of the community smears the woman's face with red ochre clay mixed with fat or Vaseline, libovu. This 
enacts emalobolo or emabheka, bridewealth transactions of cattle ${ }^{4}$ and cash, and the couples' families mark this in a rite where the man's family formally presents these items and requests the woman to move patrilocally as a new wife, makoti.. ${ }^{5}$ Because emalobolo may take years to complete, another rite, umtsimba, may take place marking the final payments and involve dancing, slaughter, and declarations to harmonise in-law relations, bukhoti. ${ }^{6}$ When the woman dies, she would ideally be buried at her husband's home. When the husband dies, her in-laws will expect her to wear mourning attire and stay in seclusion. In these ways, customary marriage is preeminently social rather than interpersonal, and is bound up with ritual obligations that extend across the life course. ${ }^{7}$

Despite their formulaic stipulations, few couples and families accomplish all of these rites in any orderly sequence or schedule, and some of course do not or are unable to have children. Sometimes emalobolo and umtsimba coalesce in a single event, or umtsimba might never be performed because subsequent ceremonies are expensive. In the majority of cases, however, couples may undertake kuteka and or an initial payment of emalobolo, but the full amount is never paid. Social actors within each family claim stakes in these gift exchanges as representative of their social obligations to care for or interact with the husband and wife. This extends to the of life too, where a surprising number of corpse custody disputes over women's bodies have come about in debates between families over marital status at death and who is obligated to bury wives and where (Golomski 2013). If, in their view, exchanges were not complete, the social field of marriage and its afterlives are dangerously ambiguous. Civil rites of marriage contrast with these customary forms of marriage and their extensive social ties. Civil rites are validated in civil law and can ceremoniously coincide with church-based or white weddings, events that entail ritual and aesthetic elements of customary marriage, but more often involve glamorised consumption 
(Mupotsa 2014). At one Pentecostal church I regularly attended, it was common at each Sunday service to read aloud marriage announcements and cite civil marital laws, as follows:

I hereby read the banns of marriage in line with sections 9 and 10 of Marriage Act number 47, between the lives of Munyaradzi, a hired-man of Bulawayo and Xolile, a spinster of Likilikili, the couple will be married at Summerfield Gardens, on the $6^{\text {th }}$ of September, any person having legal qualms or objections should direct their objections to the registrar of marriage, the offices are at Lobamba and Manzini. The registrar is Dr. Mshengu. If you have anything legal, you can direct it there (Fieldnotes, 2010).

Couples sign a registry with one of the country's 153 officers at satellite offices around the country, and signing has become significant as a part of white weddings.

In terms of contractual obligations, civil marriages are established either "in community of property" (ICP) or "out of community of property" (OCP). These lay grounds for how assets are managed throughout the duration of the marriage, as one lawyer explained to me:

A marriage in community of property $[\mathrm{ICP}]$ is one whereby the assets and liabilities of both spouses are joined together into one estate. This is the default position of our law, so unless the parties before solemnisation of their marriage opt out of this arrangement by what is called an ante-nuptial contract, the marriage will by operation of the law be in community of property. The view of the law is that husband and wife are 'one person' in the eyes of the law. Hence the debts of each spouse as well as his/her assets (before and after the solemnisation of the marriage) are fused into one joint estate which they co-own in equal undivided share (Interview, 2015).

One key condition that separates ICP and OCP is that ICP joins the individuals' assets each held separately before the marriage is solemnised or made legal, whereas in OCP, assets pre-dating 
marriage are kept separate per ante-nuptial agreements. The equal delineation of property in ICP otherwise appears fair, but men predominately control and permit access to goods and property, which is also the case in customary marriages. Men's families and entities like banks, lending agencies, and others treat women as minors who require the man's permission to undertake economic activities (WLSA 1998, Ezer et al. 2007, Nhlapo 1987), and children born of the marriage and beyond are also affected by this gendered bias. Two legal specialists working for a global human rights NGO explained this to me at an interview in Mbabane:

The whole marriage thing is so complicated and most people don't even know what they are signing up for regarding their assets and estates when they get married. They don't even ask them which one they are taking on when they do the marriage registration and many people forget which they signed up for. [ICP] is split 50-50, but the husband is the administrator of it all. The wife is a minor and he controls access to assets and can alienate her from the assets. Even in traditional marriage, it is technically [OCP], but then when it comes to how people's goods and property are moved around, it is really [ICP]. When the husband dies, the wife gets $50 \%$ and the other $50 \%$ is divided amongst her and the children at the Master of the High Court... In [OCP] a woman can keep her own estate separate that she had before the marriage and use that how she wishes to. The husband can't control her. She can make a will and there are antenuptial agreements. The children of the marriage benefit in this way, but even those children born out of wedlock benefit too (Interview, 2011).

In their view, OCP benefits women because it protects some of a woman's wealth from predation should a marriage become intolerable, and by extension, it protects children who the woman would likely end up caring for. Most women, they felt, would be overpowered by their husbands or in-laws in negotiating what rightfully belonged to and benefited them and others in 
and out of a marriage, or they would be confounded by opaque descriptions of the process by court clerks. While the 2005 constitution has fomented several important changes with regards to gender inequality surrounding marriage, property and assets, ${ }^{8}$ women's access to farm land in rural areas is still limited due to bias toward men as chiefly overseers and/or key players who negotiate land on behalf of women as their wives or kin (WLSA 1998, Rose 2002). In OCP too, ante-nuptial agreements would make provisions of financial security for children who the woman bore prior to the marriage and by a different genitor. In local vernacular, these children are "stepchildren" to the new husband and, like orphaned and vulnerable children (OVC) (Golomski 2015), they are less likely to receive affection or provisions. Overall, married women's access to and maintenance of wealth is still contested and has implications for her and her children's wellbeing.

\section{Forms of divorce}

Formal divorce is uncommon for both customary and civil marriage./It is a cultural novelty and near institutional impossibility for the former and a tenuous expensive process for the latter. Instead, martial estrangement is much more common. Indeed, according to the Ministry of Home Affairs, only 236 couples were legally divorced between February 2014 and April 2015, in contrast to the 20,000-plus marriages during the same time (Khumalo 2015). The comments on the Times of Swaziland's Facebook page over these statistics represent wider social and gender-biased perceptions of divorce, as well as discontinuities between human rights discourses interwoven into civil rites and the stipulations of customary marriage:

kunzima any ways its due generations we a living in [it's difficult and anyways it's due to the generation we are living in] bafuna imali nje kuphela cha [all they want is money, tsk] 
$d s$ dais people dnt hve $d$ true meaning of marriage they marry 4 their needs [this is that people don't have the true meaning of marriage; they marry for their needs] this gender balance madness contributed to this

I have said this and I will say it again. As long as we embrace lenonsonso lesitsi ngema Human rights expect an increase kudivorce rate. Lentfo yema rights ibulele konkhe *Ayichamani* [as long as we embrace this nonsense talking about human rights, expect an increasing divorce rate. This human rights thing will destroy everything. No way, man!] The figure is even less, considering that MOST IF NOT ALL SWAZI WOMEN cheat their husbands .Sekwaba yi Fashion kugwadla kwebafati.Ubeva batsi indvodza yaganwa nami ngiyagana. No man can agree to share his Woman with another man, hence the number of divorcees increase. Sekwabate kutiphatsa kahle kubo Make, nekuhlonipha umendvo. [It has become the fashion for women to be prostitutes. They should understand that men marry them and say, "I will get married"... Women should behave well and respect marriage.] These statements came from both men and women. One woman shot back at the comments on the final posting, saying: "Ngabe ubhemani wena, ngyafisa. [what are you smoking, I wish to know]. Why do u have to throw the blame onto women? Men have a hand in this too]." The gender bias against women is palpable due to strong socio-cultural assumptions that they are encouraged to endure in marriage and be subordinate to men as wives and mothers, however dissatisfying (Kuper 1950; Simelane 2011). Assumptions that contemporary marriage is bound up with the financial or material aspirations of each partner are also clear, which I signpost here in anticipation of discussing insurance later.. Marrying for money and needs, as the Facebook users say, refers to ICP marriages, which, upon dissolution in civil divorce law, awards each spouse half of the total estate. Because of gender bias, divorcing women are seen as greedy, and socio-cultural 
pressures, combined with social and financial costliness of legal representation, arguably contribute to fewer divorces and marital arrangements of estrangement instead.

In Swaziland, divorce from customary marriage is considered rare, if not abnormal. King Mswati III declared only death could undo a customary marriage (Dlamini 2013), and even then "remarriage" for the surviving spouse in culturally recognized sororate and levirate forms would be a likely route for some families. ${ }^{9}$ According to Nhlapo (1992), marital dissolution is instead possible in cases of: adultery committed by the wife; witchcraft committed by the wife; grossly violent mistreatment of the wife by the husband; and persistent desertion by the wife. Desertion or neglect by the husband is not considered grounds, and neither is the couple's infertility —as the husband might be expected to take another wife to bear children — and a man can still be adulterous with other, unmarried women. In forums of chiefly councils, divorce is possible when the couples' two families meet before the council, which will interpret the timing, promise, and completion of the marital rites and exchanges between the couples' families, in addition to the spouses' complaints of abuse, adultery and the like. If the council cannot help the families reconcile, the case can move into civil courts. This is costly and stressfully entangles couples, parents, and relatives, and involves ritual obligations like burial that may outlive the couples' love and co-residence.

Since the colonial area, women have accessed civil courts to leave customary marriages that were forcibly arranged or rife with violence (Kuper 1950, Booth 1992). In civil courts, contemporary lawyers and judges use anthropological citations from Nhlapo $(1992,1987)$, Kuper (1950, 1947), and others when deliberating on cases asking for the dissolution of a customary marriage. According to one lawyer I spoke to, there "is an evolving trend towards the recognition of [divorce from customary marriage on] certain grounds. Nevertheless, the rules remain very stringent and the grounds are so exceptional." For example, in cases 3046/2006 and 3822/2008 
involving wife and applicant Matry Nompumelelo Dlamini and husband Musa Clement Nkambule, Judge J. Mamba, citing Nhlapo (1992) and expert witnesses on customary law, annulled their marriage on the grounds that the families were unable to reconcile the situation on behalf of the couple, and Musa had forcibly removed Matry from their home and separated their personal belongings, an act signaling the end of marital conjugality. This case laid grounds for subsequent successful dissolutions of customary marriage in the civil courts (1570/2013 Mkhatshwa Dlamini v. Dumsile E. Dlamini; 2501/2010 Futhi Thwala v. Tengetile Dlamini). Besides the separation of personal belongings, however, these cases did not deliberate on the distribution of immovable property nor on child custody and care, but only expunged the married status from the registry.

Again in Swaziland, couples are able to divorce more clearly in civil law. Each spouse hires a lawyer to file for divorce in the courts and from which they obtain a final divorce decree if successful. ${ }^{10}$ There, grounds for divorce are two: malicious desertion and adultery. The first includes constructive desertion done maliciously—where one spouse makes life in the household intolerable or refuses conjugal rites - and actual desertion in the case where one spouse literally leaves the household. Unlike adultery in customary marriage, either spouse may be divorced on these grounds, with children born out of wedlock being the tangible evidence. Yet civil divorce law is also biased towards women (Langwenya 2012; Ezer et al. 2007), and in the case of malicious desertion the court will usually insist that the deserting partner first return and attempt to restore conjugal rights. In other words, the court would compel a woman who ran away from a violent husband to return to their household and work on the marriage. This would include the woman returning to have sex with the man. One lawyer explained to me how this is "out of tune with contemporary challenges, in particular the HIV pandemic," asking rhetorically, "why should the law require (compel) a person to have sex with his/her spouse who has been absent from the 
matrimonial homestead for years without the knowledge of the innocent spouse?" The courts therefore enforce sexual relations between spouses in estranged marriages in spite of the possibility that the extra-marital sexual relations of either partner could lead to HIV transmission between spouses. ${ }^{11}$ Recent attempts to reach beyond these stipulations by way of South African civil divorce law have failed (Nonhlanhla Sacolo v. Christopher Sacolo 4095/2008, Vusizwe Mahlalela v. Nonhlanhla Mahlalela 1926/2009), and divorce is granted only if this second attempt at resolving the marital conflict through restored conjugality fails. Hiring lawyers and the technical English-language medium of the courts also make undertaking divorce prohibitive, especially for women who are less likely to afford it and be educated (Ezer et al. 2007).

Overall, women's wellbeing can be compromised within civil divorces, and Tamar Ezer and colleagues $(2007,903)$ point out, this goes for children too, given that there are no statues systemically governing child custody. In customary law, children are said to belong to the man, and in civil law, judges tend to grant legal custody to the man and physical custody to the woman. Given that the majority of marriages are ICP, women are likely to lose out on a substantive portion of the estate, including pre-marital assets to men, thus diminishing resources potentially able to be used to care for children. Other assets, however, seem to have greater flexibility or fixity with regards to owners' identity and women's rights to consume them. For example, Ingcamu, the parastatal managing state employees' pensions, mediates the contractual division of a deceased spouse's pension to the surviving spouse and children. Insurance as an asset, however, represents an interesting intervention into this gendered, unequal socio-economic field of marriage and family life, and a possible source of vitality for women amid divorce. Secrecy and the impossible: insurance amid estrangement

Indeed, the stipulations of divorce for either customary or civil marriage are formidable, and place women and children in precarious positions that may compromise their physical, social, and 
economic wellbeing, even if women are still expected to physically care for children belonging customarily to the man's patriline. If divorce is not possible because it is either too costly or threatens to undo the greater social field in which women might find assistance for themselves and their children, women may undertake economic activities that could improve their immediate or future chances. They may maintain or engage formal wage employment (Simelane 2011) or, as for some women I describe next, continue to pay for their partner's insurance coverage surreptitiously.

First, though, insurance in Swaziland has to be contextualised. The Kingdom witnessed an influx of foreign life insurance companies in the mid 2000s, associated with changes to the financial services sector and high death rates from HIV/AIDS. Funeral or term life insurance policies quickly became hyper-monetised means to show compassion for spouses, parents, in-laws, biological children, and entrusted OVC by paying toward another vital conjuncture, that of death, by providing dignified funerals. Policies provide money, which policyholders are supposed to use to pay for a funeral and which is in greater amount than that which burial cooperatives provide. Policies list the principal member along with one or more spouses—-some applications even list options for a "tribal spouse"- and often up to four or five children, and other dependents run additional charges (Golomski 2015). Divorcing policyholders could easily revise their policies to leave off the spouse. Brokers were keen to check up on their clients in this regard, yet it was evident that people were much more secretive or surreptitious about enacting and continuing others' subscriptions as dependents (Bähre 2012).

During my participation observation on sales presentations and in interviews, many insurance personnel described a general trend where individuals subscribed to policies and listed their spouse(s) as dependents, but ultimately did not tell their spouse about the policy. Both via interview probing and in extemporaneous responses, I was told this was because of potential marital distrust and malevolence, sometimes embodied in "witchcraft." This term is used to refer 
to the actions of a person who has no "heart," one who is reprobate or has malicious intent to undo others' wellbeing. Several brokers laughingly explained how policyholders did not tell their spouses, as a spouse could potentially kill the policyholder by poisoning his or her food in order to then claim on the policyholder. Sending or placing nefarious substances in food and drink is a one example of witchcraft, butsakatsi in marriage, but the more common iteration and socio-cultural assumption is that in-laws relations are antagonistic to the extreme point of murderous accusations. Brokers often tried to work against the opaqueness between spouses and dependents, and effectively brokered these relations within families (Golomski 2015). One broker, described to an audience in a sales pitch that she was willing to call up a policyholder's in-laws to explain the policy and, by proxy, mitigate suspicions the in-laws might hold against their son- or daughter-inlaw in buying the product. In Jane Guyer's (personal communication, December 3, 2014) terms, they broker both insurance and kinship. While many consumers and brokers thought insurance was a good thing to provide for others' future deaths and wellbeing, most were also aware of an avaricious undercurrent. This dynamic also involved policyholders who did not present divorce certificates to brokers, or brokers who did not ask if couples were estranged or divorced, allowing policyholders to still make claims on others with whom they were no longer close. Accordingly, from the side of consumers, insurance premium payments were kept secret over a longer period of time. Policyholders like Tsandzile and other women I met were craftier to keep paying premiums after their divorces or estrangements. As it turned out, eventual claims would enable them to fulfill important social and ritual obligations.

For example, I lived with Msizi during fieldwork in 2009 and 2010. She is an educator and mother of four adult children, and is estranged from her husband. As a child she was sent to live with the chief of her parental community as a sort of social return on her father's behalf as he had originally obtained cattle from the chief to marry Msizi’s mother. Msizi fled to a medium-sized 
city following high school graduation, and there married to her husband Elton in civil rites. Later they married in customary rites by kuteka, although Msizi often bemoaned how Elton had never paid her family a "single cow" for emalobolo nor attended Msizi's family's ceremonial events as an in-law. I have known Msizi now for seven years and have never met Elton, who left their household to live elsewhere approximately ten years ago. As often occurs in civil marital rites and ICP, while they both have access to the house, the husband effectively owns it, although according to Msizi, he has never help pay for municipal services or taxes.

When telling her about my findings on witchcraft with the insurance brokers, she agreed it was common, saying, "this threatening thing happens with all investments. [My husband] could come back here and just take over this house if he wanted." While staying at their suburban house, we experienced several instances_-like finding a large dead crab on the stoop — which were interpreted as evidence of possible bewitchment by the husband or others and against which they prayed to God for protection. Despite all this, and saying several times she was "divorced," she remained in the house and continued to count him as a beneficiary on her state pension's funeral plan, explaining that her commitment to her husband reflected commitments to her children, because they belonged to his patriline. As she explained, they should be guaranteed the obligation to go to his family's ritual events, like others' funerals and marriages, at which latter events the children would potentially exchange and receive gifts in rites like umhlambiso. Msizi would also contribute to Elton's funeral, assuming he predeceases her. The bonds of social obligation underscored in the initial betrothal rites of customary marriage, overlaid by the gender-biased social norms that suffuse their civil rites, perpetuated a marriage where Msizi still ultimately pays for insurance coverage while remaining estranged socially and residentially from her circumspect husband.

Another example is Nonjabuliso, a self-identifiedlesbian working for a health NGO across 
the border in a town in South Africa, who explained that she recently "divorced" her partner of six years. The couple is well known to other LGBT persons in that South African town, and she described how they had long been a model couple of intimacy, romance, and co-habitation for younger lesbian couples; they often hosted parties at their shared home. Several months before I met her at her office, Nonjabuliso split from her partner and moved out from their household. She took what she considered her personal belongings: furniture, sheets and bedding, dishes and utensils, and some electronics. The couple had contemplated purchasing a car together in addition to their own respective cars, but they had not completed the transaction. During their relationship, Nonjabuliso subscribed to a funeral policy and named her partner on it as an adult, non-spousal dependent. The two could have married under South African law, unlike in Swaziland where legal institutions do not provide for this aspiration, but they did not go so far as to file, register and obtain a certificate of marriage. She explained that she would not cast off her partner from the policy, not because this would be reprobate, but because she herself would stand to benefit financially. The policy, worth roughly R5,000 (US\$450) could be divided as a small contribution to the partner's anticipated funeral, with Nonjabuliso keeping a larger proportion. Paying into and being present at the eventual funeral would also publically evidence to others, including their young lesbian comrades and friends, her fulfillment of ritual obligations bound up in marital-like social relations.

Although women and men who buy life insurance in Swaziland are not extraordinary (Golomski 2015), because of economic dispossession and inequality, many women are not able to buy into insurance or use it in this way. Take Sindisiwe as an example. Sindisiwe's mother was a diviner, sangoma, who had her daughter by a migrant labourer in South Africa. Sindisiwe never knew her father, and her mother left her in the custody of a distant relative to be raised in Swaziland while the mother went work in South Africa as a sangoma. Sindisiwe received very 
little support throughout her young adult life, but got by on ingenuity. She bought a small house outside of Manzini, and later became a young mother herself, having four children by four different men, the last by a man who she married in civil rites in 2013. Her mother died a month before this marriage, and she had no other senior relatives to make customary negotiations or presentations on her behalf to the husband or his family to develop a marital relationship aside from her signing the papers of civil rites.

Sindisiwe's new husband encouraged her to give up drinking and partying and to begin attending an evangelical Neo-Pentecostal-style church. He had taken a policy out with Sindisiwe as his spousal dependent too. But about two years into the relationship, after she had moved into his home with her other children, the relationship soured. Sindisiwe relied on him for transport and his good salary for material support, but these, and his insurance coverage for her, were fully withdrawn when he initiated a civil divorce. She had no matching policy for him, nor the funds to strategise within the divorce proceedings. "I couldn't afford a lawyer myself," she explained:

So I didn't oppose, didn't fight; [the husband and his lawyer] were just doing their own things. It wasn't right, but what I could I do? I didn't have the power. So I let him have everything. He supports me and the baby at least, and I can't fight anymore. I can't have that headache.

The lawyer compelled him to give her physical custody of their child and money for maintenance, despite his legal custody and paternity, and Sindisiwe had communicated to the lawyer the average costs of caring for the baby, including the purchase of milk and diapers. However, Sindisiwe surmises that the husband convinced the lawyer to drop the overall maintenance amount. Sindisiwe and her children moved back to her house but they have no transportation nor income other than the sporadic support she receives from her other children's fathers. They do not have an insurance policy from which to claim in the event of her ex- 
husband's death. In her view, her street smarts, and possibly a new lover will be her best resources for her immediate post-divorce future beyond finding wage employment, itself an elusive prospect.

Overall, actual divorce rates are low in Swaziland, and given the costly social and economic difficulties of obtaining a divorce, in both civil and customary marriage, many intolerable marital relationships continue in a state of estrangement. In the dissolution of marriage, future possibilities to provide for children and social others were up for grabs, and yet social and ritual obligations kept some women connected to their estranged spouses precisely through a financial consumable like insurance. The risk embodied in consumption may be worth the chance to produce some future wellbeing as both personal cash income and harmonious social relations. In this latter regard, some women could pay away a ritual obligation to their estranged husbands' in-laws, while simultaneously evidencing their children's paternity and a broader set of enduring of social commitments grounded in customary stipulations about marriage. Finally, the question of financially viable practice comes to the fore with regards to the temporality of the life course. Namely, wouldn't paying premiums after a divorce and until death be a too long and too costly lifetime endeavour? Not necessarily. The effects of the HIV epidemic have been immense, as the Kingdom has harbored the world's highest prevalence for the disease since 2007, and, at various times since the turn of the Millennium, the world's lowest life expectancy. ${ }^{12}$ Given these demographic conditions, the macabre prospect of quicker death and quicker cash windfall is not so far off, and heightens even more what Rosalind Morris (2008) called the economised "speculation" surrounding HIV/AIDS mortality.

\section{Conclusion: love and money}


Although women are often disadvantaged in marriage, the prospect of discreet access to cash through an insurance policy evinces a "horizon" of possibilities, to use Johnson-Hanks' (2002, 872) terms. The number of women doing this may not be statistically significant, but the few who take on the risk represent agentive actions amid social, legal and economic dispossession with the aim to better their lives as single women and mothers. Secrecy mediated spouses' and families' actions of insurance consumption via forms of divorce for both customary and civil marriage. Anita Hardon and Deborah Posel (2012; also Hirsch et al. 2009, Davis and Manderson 2014) point out how secrecy is both a social and bodily practice, one enabling or disabling others to witness effects of illness and injury. In Swaziland, as a bodily practice, the physical scars of domestic violence like Tsandzile's from her husband's brutality are mediated through adornment and circumspection amongst colleagues. As a social practice, I suggest, women's continuing payment of insurance for husbands represents a secretive "tactic to assert an advantage" (Hardon and Posel 2012, S4), one of "self-determination" (Livingston 2009) which aims toward a better life. The risk involved is indeed social, economic, and physical. Julie Livingston (2009) harrowingly describes how investments suffuse marital-love relations in Botswana, and yet failures to accomplish them can lead to partners' suicides and passion killings. This was not unlike women facing the vital conjuncture of divorce and its potential attendant forms of domestic violence or witchcraft accusations in Swaziland's insurance market.

What has yet to be said regarding marriage and divorce concerns love. Do these women still love their husbands as another reason for continuing insurance coverage? Tsandzile and Sindisiwe said they no longer loved their husbands. Nonjabuliso said she still loved her partner, and Msizi simply made a puckered face. While one could report simple statements of yes or no, it would be more accurate to situate their subjective articulations of love within broader socioeconomic and historical contexts of gendered dispossession. Mark Padilla and colleagues (2007; 
Bear et al. 2015) describe how global political economic inequalities manifest locally and organise experiences of love and intimacy. While women are unequal figures in both forms of marriage, bringing to light their subjective intentions to fulfill obligations toward in-laws on behalf of their children through insurance policies hearkens to Padilla's and colleagues' (2007) suggestion that studies of kinship — including forms of estrangement — are expanded when taking into account feminist perspectives on gender inequality. Similarly in Africa, according to Jennifer Cole and Lynn Thomas (2009), emergent forms of romantic love implore heightened forms of material exchange in gifts and support between spouses, and women draw on notions of love to transcend customary, patriarchal forms of dispossession. However, in the end, women tend to find themselves confounded in love relations by the equally dispossessive legal and financial forms of neoliberalism. Love as ideal type does not equate with lived experience, and some of these women, like Sindisiwe, go on to find new loves in the space of their estranged relations.

In a final note then, few women in Swaziland navigated vital conjunctures like series of marital rites, divorce, and estrangement through insurance. Doing so shows howshifting subjective dimensions of intimate relationships are bound up with with the shifting forces of custom and economy and institutions' in-abilities to manifest forms of social life people aspire to.. The situation points not to women's avarice or that they are not behaving themselves" as the misogynist Facebook posts claimed. It points to women's abilities to find inventive solutions for possible better futures for themselves and their children who they love and (feel) obligated to care for.

\section{Acknowledgements}

I am thankful to the women, families, and insurance market personnel in Swaziland for describing these complex processes and often-difficult circumstances. Sonene Nyawo aided me in finding 
additional interviewees. Nolwazi Mkhwanazi and Jessica Hardin did closer critical readings of the

paper. A final thanks goes to Lenore Manderson, Hylton White, and Ellen Block for the invitation to participate in this timely project.

\section{Disclosure}

The research was funded in part by the Department of Anthropology and the University Research Council of the University of the Witwatersrand. There are no conflicts of interest to report.

\section{References}

Bähre, Erik. 2012. “The Janus Face of Insurance in South Africa: From Costs to Risks, from Networks to Bureaucracies." Africa 82 (1): 150-168. doi:10.1017/S0001972011000787.

Bear, Laura, Karen Ho, Anna Tsing, and Sylvia Yanagisako. 2015. “Gens: A Feminist Manifesto for the Study of Capitalism." Fieldsights - Theorizing the Contemporary, Cultural Anthropology Online, March 30. Accessed March 3, 2016. http://www.culanth.org/fieldsights/652-gens-afeminist-manifesto-for-the-study-of-capitalism.

Bicego, George, Rejoice Nkambule, Ingrid Peterson, Jason Reed, Deborah Donnell, Henry Ginindza, Yen Duong, Hetal Patel, Naomi Bock, Neena Philip, Cherry Mao, and Jessica Justman. 2013. "Recent Patterns in Population-Based HIV Prevalence in Swaziland." PLoS One 8 (10): e77101. doi:10.1371/journal.pone.0077101. 
Booth, Alan. 1992. “"European Courts Protect Women and Witches’: Colonial Law Courts as Redistributors of Power in Swaziland, 1920-1950." Journal of Southern African Studies 18 (2): 263-275. doi:10.1080/03057079208708314.

Buchanan, Elizabeth A., and Michael Zimmer. 2016. "Internet Research Ethics." In The Stanford Encyclopedia of Philosophy (Spring 2016 Edition), edited by Edward N. Zalta. Accessed March 4, 2016. http://plato.stanford.edu/archives/spr2016/entries/ethics-internet-research/.

Central Statistical Office (CSO) [Swaziland] and Macro International. 2008. Swaziland Demographic and Health Survey 2006-07: Key Findings. Calverton, Maryland: CSO and Macro International.

Cole, Jennifer, and Lynn Thomas, eds. 2009. Love in Africa. Chicago, IL: University of Chicago Press.

Davis, Mark and Lenore Manderson, eds. 2014. Disclosure in Health and Illness. New York: Routledge.

Dlamini, Welcome. 2013. "No Divorce in Swazi Marriages - King." Times of Swaziland August 12.

Dorjahn, Vernon. 1990. “The Marital Game, Divorce, and Divorce Frequency among the Temne of Sierra Leone.” Anthropological Quarterly 63 (4): 169-182. 
Ellis, Walter L. 2003. "Urban and Rural Differences in the Provision of Health Insurance Coverage for Children of Divorce." Journal of Divorce and Remarriage 38 (3-4): 31-39. doi: 10.1300/J087v38n03_02.

Ezer, Tamar, Aisha Glasford, Elizabeth Hollander, Lakeisha Poole, Grant Rabenn, and Alexandria Tindall. 2007. "Divorce Reform: Rights and Protections in the New Swaziland." Georgetown Journal of Gender and Law 8: 883-993.

Golomski, Casey. 2013. “Right Passages: Work, Ritual, and Regeneration in Swaziland's Age of HIV/AIDS.” PhD diss., Brandeis University.

Golomski, Casey. 2015. “Compassion Technology: Life Insurance and the Remaking of Kinship in Swaziland's Age of HIV.” American Ethnologist 42 (1): 81-96. Doi: 10.1111/amet.12117.

Hardon, Anita and Deborah Posel. 2012. "Secrecy as Embodied Practice: Beyond the Confessional Imperative.” Culture, Health \& Sexuality 14 (S1): S1-S13. doi:10.1080/13691058.2012.726376.

Hirsch, Jennifer, Holly Wardlow, Daniel Jordan Smith, Harriet Phinney, Shanti Parikh, and Constance Nathanson. 2009. The Secret: HIV and Marriage. Nashville, TN: Vanderbilt University Press.

James, Deborah. 2015. Money from Nothing: Indebtedness and Aspiration in South Africa. Renwood City, CA: Stanford University Press. 
Johnson-Hanks, Jennifer. 2002. "On the Limits of Life Stage Ethnography: Toward a Theory of Vital Conjunctures.” American Anthropologist 104 (30): 865-880. doi:10.1525/aa.2002.104.3.865.

Kennedy, Caitlin, Stefan D. Baral, Rebecca Fielding-Miller, Darrin Adams, Phumlile Dludlu, Bheki Sithole, Virginia Fonner, Zandile Mnisi, and Deanna Kerrigan. 2013. “They are Human Beings, They are Swazi’: Intersecting Stigmas and the Positive Health, Dignity, and Prevention Needs of HIV-Positive Men Who Have Sex With Men in Swaziland.” Journal of the International AIDS Society 16 (suppl. 3): 18749. doi:10.7448/IAS16.4.18749.

Khumalo, Stanley. 2015. “236 Divorces in 11 Months.” Times of Swaziland, March 6.

Kuper, Hilda. 1947. An African Aristocracy: Rank among the Swazi. Oxford, UK: Oxford University Press.

Kuper, Hilda. 1950. "Kinship among the Swazi.” In African Systems of Kinship and Marriage, edited by A. R. Radcliffe-Brown and Darryl Forde, 86-110. Oxford, UK: Oxford University Press.

LaNgwenya, Maxine. 2012. "Historic Step Towards Equality for Swazi Women: An Analysis of Mary-Joyce Doo Aphane v. the Registrar of Deeds." Open Debate, 6. Parktown, South Africa: Open Society Initiative of Southern Africa (OSISA). Accessed March 6, 2016: http://www.osisa.org/sites/default/files/open_debate_6_-doo_aphane_v_registrar.pdf. 
Lavelle, Bridget, and Pamela J. Smock. 2012. “Divorce and Women's Risk of Health Insurance Loss." Journal of Health \& Social Behavior 53 (4): 413-431. doi:10.1177/0022146512465758.

Livingston, Julie. 2009. "Suicide, Risk, and Investment the Heart of the African Miracle." Cultural Anthropology 24 (4): 652-680. doi:10.1111/j.1548-1360.2009.01043.x.

Lloyd, Sally A., Beth C. Emery, and Suzanne Klatt. 2009. “Discovering Women's Agency in Response to Intimate Partner Violence.” In Handbook of Feminist Family Studies, edited by Sally A. Lloyd, April L. Few, and Katherine R. Allen, 264-278. London: SAGE.

Lynch, Caitrin, and Jason Danely, eds. 2013. Transitions and Transformations: Cultural Perspectives on Aging and the Life Course. New York: Berghahn.

Medeiros, Melanie. 2014. "The Other End of the Bargain: The Socioeconomics of Marital Dissolution in Rural Northeast Brazil.” Transforming Anthropology 22 (2): 105-120. doi: 10.1111/traa.12032.

Mkhwanazi, Nolwazi. 2014. “'An African Way of Doing Things': Reproducing Gender and Generation." Anthropology Southern Africa 37 (1-2): 107-118. doi:10.1080/23323256.2014.969531.

Morris, Rosalind. 2008. "Rush/Panic/Rush: Speculations on the Value of Life and Death in South Africa's Age of AIDS.” Public Culture 20 (2): 199-231. doi:10.1215/08992363-2007-024. 
Mupotsa, Danai S. 2014. “White Weddings.” PhD diss., University of the Witwatersrand.

Nhlapo, Thandabantu. 1987. "Law Versus Culture: Ownership of Freehold Land in Swaziland." In Women and the Law in Southern Africa, edited by Alice Armstrong and Welsh Ncube, 35-55. Harare, Zimbabwe: Zimbabwe House Publishers.

Nhlapo, Thandabantu. 1992. Marriage and Divorce in Swazi Law and Custom. Mbabane, Swaziland: Websters.

Nyawo, Sonene. 2015. “'Sowungumuntfu ke nyalo - Now you are a Real Person’: A Feminist Analysis of how Women's Identities are Constructed by Societal Perceptions on Fertility in the Swazi Patriarchal Family.” PhD diss., University of KwaZulu-Natal.

Risher, Kathryn, Darrin Adams, Bheki Sithole, Sosthenes Ketende, Caitlin Kennedy, Zandile Mnisi, Xolile Mabuza, and Stefan D. Baral. 2013. "Sexual Stigma and Discrimination as Barriers to Seeking Appropriate Healthcare among Men Who Have Sex With Men in Swaziland.” Journal of the International AIDS Society 16 (suppl. 2): 18715. doi:10.7448/IAS.16.3.18715.

Rose, Laurel. 2002. "Women's Strategies for Customary Land Access in Swaziland and Malawi: A Comparative Study." Africa Today 49 (2): 123-149. doi:10.1353/at.2003.0014.

Padilla, Mark, Jennifer Hirsch, Robert Sember, Miguel Muñoz-Laboy, and Richard Parker. 2007. Love and Globalization. Nashville, TN: Vanderbilt University Press. 
Peters, H. Elizabeth, Kosali Simons, and Jamie Taber. 2014. "Marital Disruption and Health Insurance.” Demography 51 (4): 1397-1421. doi:10.1007/s13524-014-0317-6.

Simelane, Hamilton Sipho. 2011. “'Sharing my Bed with the Enemy': Wives and Violent Husbands in Post-Colonial Swaziland." Journal of Contemporary African Studies 29 (4): 493-512. doi:10.1080/02589001.2011.601045.

Stiles, Erin. 2003. "When Is a Divorce a Divorce? Determining Intention in Zanzibar's Islamic Courts.” Ethnology 42 (4): 273-288. doi: 10.2307/3773829.

Stiles, Erin. 2005. “'There is No Stranger to Marriage Here!' Muslim Women and Divorce in Rural Zanzibar.”Africa 75 (4): 582-598. doi:10.3366/afr.2005.75.4.582.

US Department of State. 2011. Country Reports on Human Rights Practices for 2011: Swaziland. Washington D.C.: US Department of State Bureau of Democracy, Human Rights and Labor. Accessed March 5, 2016: http:/www.state.gov/documents/organization/186458.pdf.

Van Schalkwyk, Adelle. 2006. "The Indigenous Law of Contract with Particular Reference to the Swazi in the Kingdom of Swaziland." PhD diss., University of South Africa.

WLSA (Women and Law in Southern Africa Research Trust). 1998. Family in Transition: The Experience of Swaziland. Manzini, Swaziland: Ruswanda Publishing.

Court cases 
Futhi Thwala (nee Dlamini) v. Tengetile Dlamini Others (2501/08) [2012] Swaziland High Court 5 (9 January 2012)

Mkhatshwa Dlamini v. Dumsile Elizabeth Dlamini (nee Seyama) and Two Others (1570/2013) [2014] Swaziland High Court 163 (21 July 2014)

Matry Nompumelelo Dlamini and Others v. Musa Clement Nkambule and Others (3046/2006, 3822/2008) [2009] Swaziland High Court__ (8 August 2009)

Vusizwe Mhlalela v Nonhlanhla Mahlalela (nee Dlamini) (1926/09) [2013] Swaziland High Court 17 (8 February 2013)

Nonhlanhla Sacolo v. Christopher Sacolo and Others (4095/2008) [2010] Swaziland High Court _ (8 July 2010)

Sheila Nondumiso Nhlabatsi v. Phineas Stanford Dlamini and 2 Others (1549/2012) [2014] Swaziland High Court 16 (19 February 2014)

\section{Notes}

\footnotetext{
${ }^{1}$ I thank Jessica Hardin for suggesting this provocative phrase.

${ }^{2}$ Document research included tracking stories in local newspapers in their print and digital formats, including newspapers' Facebook posts of their stories and public commentary. Because comments were on a page of the newspaper, a public entity, rather than on users' personal pages,
} 
and that such comments are made to publically viewable, these data fail to meet standard regulatory definitions of private information according to many human ethics research clearance standards (Buchanan and Zimmer 2016). Like these data, all interviewees and persons described ethnographically are anonymised in this article. The original research was cleared by the Brandeis University Committee for Protection of Human Subjects.

${ }^{3}$ The same two spouses may marry each other under both customary and civil forms.

${ }^{4}$ Of major importance is the presentation of a two types of beasts, one to be killed for feasting at the event, lugege, and another for the mother of the woman, insulanyembeti, mean to "wipe the tears" of the mother over her daughter's egress.

${ }^{5}$ The woman's family reciprocates with gifts for the man's family, umhlambiso. The gifts include sets of domestic items like grass mats, bathing basins, and blankets given to each sibling of the man.

${ }^{6}$ Between emalobolo and umtsimba, another rite hosted by the husband's family may take place that signals the woman has thus far been good in her domestic, motherly and wifely duties. Here, a goat is slaughtered and the woman is now permitted to eat sour milk, emasi, and eggs in front of her in-laws.

${ }^{7}$ While the reported median age of first marriage for men $30-49$ is 27.7 years and women 24.3 years (Central Statistical Office 2008), the long-term production of marriage through the series of customary exchanges and the dual legal system suggests we question which rite or legal system is being referenced in asking people to report their marital status and what social obligations are attendant to it at that point.

${ }^{8}$ For example, until the 2011 court case of Mary-Joyce Doo Aphane, women still were obliged to take the surname of their husband in civil rites when jointly registering immovable property. 
Parliament is still deliberating on whether to make this into law, but registry officers now allow couples to sign their respective names (Langwenya 2012).

${ }^{9}$ Levirate marriage, or "widow inheritance" is kungena, where a brother of a deceased man may marry the widow, while kuhlanta as sororate marriage refers to the sister of a woman who may also marry the woman's husband or bear a child on her behalf should she not be able to. Remarriage outside of these forms is rare, but if it does occur the bride is again smeared but with animal fat, liphehla, rather than the red ochre (van Schalkwyk 2006: 186). There are no official state figures on rates of second marriages or formal remarriages, but popular discourse in news media and churches criticise the practice generally.

${ }^{10}$ Recently too, where couples are married under both forms of marriage_ _ "bigamy” or "dual marriage"- divorce from civil rites simultaneously enacts a divorce from customary rites (Sheila Nhlabatsi v. Phineas Dlamini 1549/2012).

${ }^{11}$ This is a serious local concern, given that Swaziland has carried the world's highest HIV prevalence since the late 2000 s, and that disease transmission is highest and most likely to occur for heterosexual, married couples (Bicego et al. 2013).

${ }^{12}$ The sources and statistics for citing the world's lowest life expectancy in Swaziland have been varied, but have ranged from between 31 years in 2004 to 28 in 2012 (Golomski 2013: 82-84). 